\title{
Effect of Time, C/N Ratio and Molasses Concentration on Saccharomyces Cerevisiae Biomass Production
}

\author{
Sokchea $\mathrm{H}^{1^{*}}$, Thi Hang $\mathrm{P}^{2}$, Dinh Phung L², Duc Ngoan L², Thu Hong $\mathrm{TT}^{2}$ and Borin $\mathrm{K}^{1}$ \\ ${ }^{1}$ Department of livelihood community, Ministry of Environment, Cambodia \\ ${ }^{2}$ Faculty of Animal Science and Veterinary Medicine, Hue University of Agriculture and Forestry, Hue University, Vietnam
}

${ }^{*}$ Corresponding author: Sokchea H, Department of livelihood community, Ministry of Environment Building Morodok Decho (503), Tonle Basak, Chamkar Mon, Phnom Penh, Cambodia, Tel: 85512737136, E-mail: huysokchea@gmail.com

Citation: Sokchea H, Thi Hang P, Dinh Phung L, Duc Ngoan L, Thu Hong TT, et al. (2018) Effect of Time, Urea and Molasses Concentration on Saccharomyces Cerevisiae Biomass Production. J Vet Ani Res 1: 104

Article history: Received: 05 May 2018, Accepted: 15 August 2018, Published: 16 August 2018

\begin{abstract}
Yeast is one of the potential microorganisms to be utilized as a feed supplement for animals due to its high nutritional value, mainly protein and organic matter content. It could be used for varieties of substrates of agricultural and industrial byproducts. Yeast utilization into animal diet would improve the intestinal environment, especially on digestibility tract, prevent colonization of pathogenic bacteria in small intestine, and also systemic immune functions. To be more proof, this experiment was to introduce and to promote the yeast biomass of Saccharomyces cerevisiae as growth promotor to improve the animal feed nutrition. The experiment was conducted by nested model with 3 replicates to determine the effects of time, carbon and nitrogen ratio $(\mathrm{C} / \mathrm{N})$ and molasses concentration within $\mathrm{C} / \mathrm{N}$ ratio of the growth medium on yeast biomass. The molasses concentrations could be used from lowest to highest, while different levels of urea levels of $0.5,1.0,1.5$ and $2.0 \%$ were used to calibrate the ratio of $\mathrm{C} / \mathrm{N}$ in the medium for the grow of yeast.

As the result, variations in fermentation time had the greatest impact on the biomass of Saccharomyces cerevisiae. The best fermentation time for obtaining optimum production of yeast biomass to be at $24 \mathrm{~h}$. Biomass of yeast was highest at $\mathrm{C} / \mathrm{N}$ ratio of $10 / 1$ reached $6.68 \mathrm{~g}$ $\mathrm{L}^{-1}$. At a concentration of molasses at $35.00 \mathrm{~g}$ within $\mathrm{C} / \mathrm{N}$ ratio of $10 / 1$ gave highest biomass of yeast, reached $7.57 \mathrm{~g} \mathrm{~L}^{-1}$.
\end{abstract}

Keywords: Biomass of Saccharomyces Cerevisiae Yeast; Molasses; Urea Levels

\section{Introduction}

Saccharomyces cerevisiae has been used to produce foods such as bread, wine, sake and beer by human. In recently times, Saccharomyces cerevisiae was used to produce single cell protein as an animal feed supplement in animal production [1]. In monogastric animals, the use of live yeast to improve feed nutrition has become more popular when the Europe bans using antibiotics since 2006 as an antibiotic growth promoter in animal production. Any application of antibiotic as growth-promoters in the animals feed would improve the resistance of pathogenic bacteria to antibiotics that may be used in clinical or veterinary practice (Hughes, 2004). Maron, et al., 2013 also indicated that U.S restricted any antimicrobial use, following to scientific evidence to preserve the efficacy of antimicrobial drugs for treatment of infections in humans and animals $[2,3]$.

Use of Saccharomyces cerevisiae to the diet of pigs affected the intestinal environment, improved growth rate and digestibility, prevented colonization of pathogenic bacteria in small intestine, and increased systemic immune functions [4-6]. There have been several studies on the use of Saccharomyces cerevisiae to ferment cassava pulp and root for animal feed [7-9]. The result of those studies suggests that cassava root and cassava by-product can be nutritionally improved with Saccharomyces cerevisiae for animal feeding. Tefera T, et al. (2014) also reported that fermentation of cassava root meal with starter cultures of yeast of Saccharomyces Cerevisiea resulted in elevation of crude protein (CP) and decreased $\mathrm{pH}$, free cyanide (FC) and moisture contents. However, in order to increase biomass of Saccharomyces cerevisiae, the substrate must have enough soluble carbohydrate and nitrogen for the growth of yeast cells [10]. Danesi, et al. (2006) reported that the type and concentration of carbon and nitrogen sources, as well as the $\mathrm{C}$ and $\mathrm{N}$ ratio of the medium for Saccharomyces cerevisiae cultivation influence cellular growth [11]. The results for cell concentration demonstrated that the use of sugarcane blackstrap molasses and yeast extract at a $\mathrm{C}$ and $\mathrm{N}$ ratio of 10 gave the highest biomass of yeast. Yeasts of saccharomyces cerevisiae usually can use some of the amino acids in molasses, but addition of nitrogen sources from urea is required. Pretreatment of yeast with urea solution enhanced the ability of yeast cell to use urea and elevated 
the biomass yield [12,13]. Manikandan and Viruthagiri (2010) reported that nitrogen source, nitrogen concentration and carbon to nitrogen ratio affect biomass concentration [14]. Supplementation of yeast into the animal feed may boost ADG, augment mucosal immunity, promote intestinal development, adsorb mycotoxins, and reduce post-weaning diarrhea and improvement of immune modulation [15-17]. The feed with supplementation of live yeast may result in increased villus heights and villus-tocrypt ratios which would increase the internal surface of the intestinal walls making available a greater surface area for absorption $[16,18]$. From the above reason, the study therefore aimed to examine the effect of time, $\mathrm{C} / \mathrm{N}$ ratio and molasses concentration in the growth medium on yeast Saccharomyces cerevisiae biomass production.

\section{Material and Methods}

\section{Yeast Strain and Preparation}

Feed Active Dry Yeast of ICFOOD Company was used in this experiment. One gam of yeast was diluted with sterile distilled water in the range of $10^{-1}$ to $10^{-8}$ for testing density of yeast in the product. Urea were originated by the companies, distilled water was produced in the Hue University Agriculture and forestry by water distillation machine directly connected with tap water while molasses of the by-product of sugar manufacturing was used.

\section{Experimental Design}

The experiment was designed by nested model with three replicates.

Calculation $\mathrm{C} / \mathrm{N}$ ratios as below:

Bacteria and microorganisms use carbohydrates (sugar, starch and cellulose) as a food to generate energy and to grow to produce proteins and new cells. The percentage of the assimilated carbon with respect to metabolized feed carbon, is defined as the microbial conversion efficiency, and is in the range of 40-60\% [19]. According to Willett and Morrison, (2006), molasses is approximately $40 \%$ carbon [20]. Therefore, in order to get $\mathrm{C} / \mathrm{N}$ ratio of $5: 1$, molasses requirement is $25 / 1$. At urea $0.5 \%$ contains $0.23 \mathrm{~g} \mathrm{~N}$, so that added molasses to medium is $0.23 \times 25=5.75 \mathrm{~g}$, the remain of water and yeast is $=100-(0.5 \mathrm{~g}$ urea $+5.75 \mathrm{~g}$ molasses $)=93.75 \mathrm{~g}$. The calculation for $\mathrm{C} / \mathrm{N}$ ratios of 10:1 and 15:1 is similar.

The medium for growing of yeast consists of molasses, urea and water. The carbon source used in all experiments came from one sole of molasses. Urea was used as the only nitrogen rich substrate. The molasses and water were autoclaved at $121^{\circ} \mathrm{C}$ for 15 minutes, then cooled and the urea added to the medium (Table 1). The necessary quantity of raw molasses and nitrogen were calculated as in Table 1.

\begin{tabular}{|c|c|c|c|c|c|c|c|c|c|c|c|}
\hline \multicolumn{4}{|c|}{$\mathrm{C} / \mathrm{N}=5 / 1$} & \multicolumn{4}{|c|}{$\mathrm{C} / \mathrm{N}=10 / 1$} & \multicolumn{4}{|c|}{$\mathrm{C} / \mathrm{N}=15 / 1$} \\
\hline $\begin{array}{l}\text { Urea } \\
(\mathrm{g})\end{array}$ & $\begin{array}{l}\text { Molasses } \\
\text { (g) }\end{array}$ & $\begin{array}{l}\text { Yeast } \\
(\mathrm{g})\end{array}$ & $\begin{array}{c}\text { Water } \\
(\mathrm{g})\end{array}$ & $\begin{array}{c}\text { Urea } \\
(\mathrm{g})\end{array}$ & $\begin{array}{l}\text { Molasses } \\
\text { (g) }\end{array}$ & $\begin{array}{c}\text { Yeast } \\
(\mathrm{g})\end{array}$ & $\begin{array}{c}\text { Water } \\
(\mathrm{g})\end{array}$ & $\begin{array}{l}\text { Urea } \\
(\mathrm{g})\end{array}$ & $\begin{array}{c}\text { Molasses } \\
\text { (g) }\end{array}$ & $\begin{array}{l}\text { Yeast } \\
(\mathrm{g})\end{array}$ & $\begin{array}{c}\text { Water } \\
(\mathrm{g})\end{array}$ \\
\hline 0.5 & 5.75 & 0.1 & 93.65 & 0.5 & 11.67 & 0.1 & 87.73 & 0.5 & 17.50 & 0.1 & 81.90 \\
\hline 1.0 & 11.67 & 0.1 & 87.23 & 1.0 & 23.33 & 0.1 & 75.57 & 1.0 & 35.00 & 0.1 & 63.90 \\
\hline 1.5 & 17.50 & 0.1 & 80.90 & 1.5 & 35.00 & 0.1 & 63.40 & 1.5 & 52.50 & 0.1 & 45.90 \\
\hline 2.0 & 23.33 & 0.1 & 74.57 & 2.0 & 46.67 & 0.1 & 51.23 & 2.0 & 70.00 & 0.1 & 27.90 \\
\hline
\end{tabular}

Table 1: The medium for yeast fermentation

\section{Measurements}

\section{Density Test}

Serial tenfold dilution from $10^{-1}$ to $10^{-8}$ of the yeast suspensions were cultured on Yeast Extract Peptone Dextrose (YPD) agar plates containing $10 \mathrm{~g} \mathrm{~L}^{-1}$ yeast extract, $20 \mathrm{~g} \mathrm{~L}^{-1}$ peptone, $20 \mathrm{~g} \mathrm{~L}^{-1}$ glucose and $20 \mathrm{~g} \mathrm{~L}^{-1}$ agar and incubated for $48 \mathrm{~h}$ at $30{ }^{\circ} \mathrm{C}$ and monitored for 3 days. All the plates containing from 20-300 colony on the plate were counted.

The number of colony forming units (CFU), standing for $(N)$ can be calculated by using equation:

$$
N=n / D F \times V
$$

\section{Where:}

$n$ = number of colonies forming units on a plate counted;

$D F=$ dilution factor; and

$V=$ Volume of sample.

\section{Identification of Yeast}

One g of yeast was cultured in $100 \mathrm{~mL}$ YPD medium at $30{ }^{\circ} \mathrm{C}$ for $24 \mathrm{~h}$. Then $100 \mu \mathrm{YPD}$ medium containing yeast were cultured on YPD agar at $30^{\circ} \mathrm{C}$ for 3 days. After that, three colonies on those plates were randomly selected as pure colonies for culturing on 
YPD medium to collect biomass cell for extract DNA. The genomic DNA of the yeast was extracted using the QIAamp DNA Stool Mini Kit. Genomic DNA was stored at $4{ }^{\circ} \mathrm{C}$ until analysis.

\section{PCR Amplification of the ITS Region}

Two universal fungal primers (ITS1: 5'-TCCGTAGGTGAACCTGCGG-3' and ITS4:

5'-TCCTCCGCTTATTGATATGC-3') were used to amplify ITS region of fungi. The PCR amplification reactions were performed in a total volume of $50 \mathrm{ml}$. Each reaction mixture contained $2 \mathrm{ml}$ of template DNA solution, $50 \mathrm{pmol}$ of each primer, $250 \mathrm{mmol}$ of each dNTP and $2 \mathrm{ml}$ of polymerase (Taq Polymerase and Taq gold DNA Polymerase; Perkin Elmer, Foster City, Calif., USA; Taq DNA polymerase, Qiagen, Hilden, Germany; Taq polymerase, Sigma, St Louis, Mo., USA) in an appropriate reaction buffer specific for each enzyme. The PCR was carried out in a MJ MiniTM Personal Thermal Cycler (BioRad) using the following program: 95 ${ }^{\circ} \mathrm{C}$ for $5 \mathrm{~min}$, followed by 35 cycles consisting of $90 \mathrm{~s}$ at $95^{\circ} \mathrm{C}, 45 \mathrm{~s}$ at $50{ }^{\circ} \mathrm{C}$ and $90 \mathrm{~s}$ at $72{ }^{\circ} \mathrm{C}$. The last extension step at $72{ }^{\circ} \mathrm{C}$ was 5 min long. PCR products were stored at $4{ }^{\circ} \mathrm{C}$ before checking by electrophoresis. The final PCR products were checked in $2 \%$ agarose gels.

PCR products were sent to Macrogen Korea for sequence by Viet A Medical Company.

\section{Cultivation Process of Yeast}

Experiment was carried out in $250 \mathrm{~mL}$ flasks containing $150 \mathrm{~mL}$ of culture medium, an initial cell concentration of $1.0 \mathrm{~g} \mathrm{~L}^{-1}$. Cultures were incubated on a rotary shaker at $180 \mathrm{rpm}$ and $30^{\circ} \mathrm{C}$ for $28 \mathrm{~h}$. Molasses was used with different levels, corresponding to C: $\mathrm{N}$ ratios of 5, 10 and 15. Urea was used as nitrogen rich substrate at different concentrations of $0.5,1.0,1.5$ and $2.0 \%$.

\section{Analytical Procedures}

Samples were withdrawn at $0,4,8,12,24$ and $28 \mathrm{~h}$ of cultivation for determination of cell biomass. Cell biomass $\left(\mathrm{X} \mathrm{g} \mathrm{L}^{-1}\right)$ was determined according to Danesi, et al. (2006) [11]. $15 \mathrm{~mL}$ of cultivation was filtered through a $0.45 \mu \mathrm{m}$ acetate cellulose membrane (Millipore, Bedford, MA). The cell biomass expressed as $\mathrm{g}$ dry cell $\mathrm{L}^{-1}$, was measured by drying the cell cake until constant weight $\left(105^{\circ} \mathrm{C}\right.$ for $\left.2 \mathrm{~h}\right)$. The overall cell productions $\left(\mathrm{X} \mathrm{g} \mathrm{L}^{-1}\right)$ were calculated according to equation:

$$
\begin{gathered}
\qquad X=\Delta X / \Delta t \\
\text { Where: } \Delta X=X_{\max }-X_{i}
\end{gathered}
$$

$\mathrm{X}_{\max }$ is the maximum cell concentration $\left(\mathrm{g} \mathrm{L}^{-1}\right), \mathrm{X}_{\mathrm{i}}$ the initial cell concentration $\left(\mathrm{g} \mathrm{L}^{-1}\right)$.

$\Delta \mathrm{t}=\left(\mathrm{t}_{\mathrm{f}}-\mathrm{t}_{\mathrm{i}}\right), \mathrm{t}_{\mathrm{f}}$ is the time corresponding to the maximum cell concentration; $\mathrm{t}_{\mathrm{i}}$ is the initial cultivation time $(\mathrm{h})$.

\section{Data Analysis}

Data were analyzed by nested design of the SPSS software. The model is:

$Y=$ mean + time $+C / N$ ratio + molasses within $\mathrm{C} / \mathrm{N}$ ratio $+e$

With this model we can answer effects of time, $\mathrm{C} / \mathrm{N}$ ratio and molasses within $\mathrm{C} / \mathrm{N}$ ratio on yeast biomass production.

\section{Results}

\section{Density of Yeast}

The result on density of yeast in Feed Active Dry Yeast of ICFOOD Company was presented in Table 2. The number of colony forming unit (CFU)/g of yeast in the product from $21.84 \times 10^{9}$ to $21.88 \times 10^{9}$. This result was consistent with the result of the yeast cell density recorded by the manufacturer.

\begin{tabular}{|c|c|c|c|}
\hline Replication & \multicolumn{3}{|c|}{ Dilution } \\
\hline & $\mathbf{1 0}^{-6}$ & $\mathbf{1 0}^{-\mathbf{7}}$ & $\mathbf{1 0}^{-\mathbf{8}}$ \\
\hline 1 & 201 & 20 & 1 \\
\hline 1 & 217 & 21 & 2 \\
\hline 1 & 189 & 23 & 5 \\
\hline 2 & 239 & 25 & 2 \\
\hline 2 & 244 & 21 & 3 \\
\hline 2 & 220 & 19 & 2 \\
\hline 3 & 240 & 23 & 2 \\
\hline 3 & 195 & 24 & 3 \\
\hline 3 & 211 & 21 & 1 \\
\hline Total CFU/g & $21.84 \times 10^{9}$ & $21.88 \times 10^{9}$ & \\
\hline
\end{tabular}

Table 2: Density of yeast in Feed Active Dry Yeast product 


\section{Identification of Yeast}

Amplification of the ITS region yielded clear products without by-products, for all three samples of DNA band with a size of approximately 800 bp as determined by electrophoresis in $2 \%$ agarose gels (Figure 1 ).

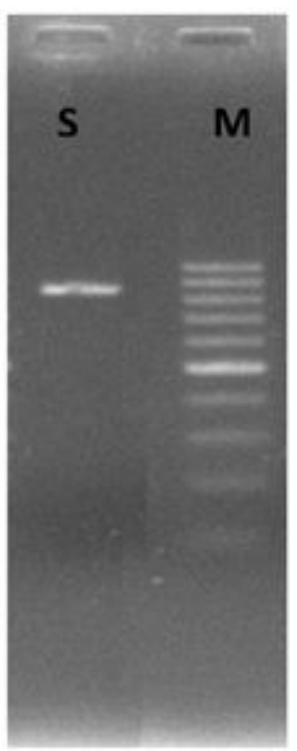

A

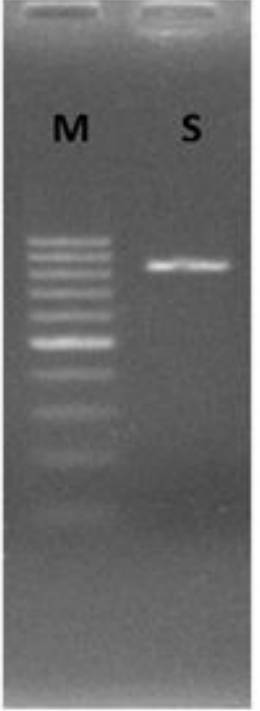

B

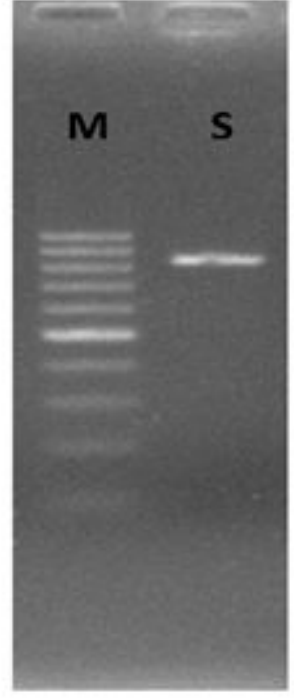

C

Figure 1: DNA band of three DNA samples from 3 colonies (A-C) of yeast on agarose gels

S: DNA sample of each colony of yeast; M: ladder $100 \mathrm{bp}$

\begin{tabular}{|c|c|c|c|c|}
\hline DNA band & Closest sequence & Accession no. & $\begin{array}{c}\text { Identity } \\
\mathbf{( \% )}\end{array}$ & Length of DNA \\
\hline 1 & Saccharomyces cerevisiae & KY105179 & 99 & 646 \\
\hline 2 & Saccharomyces cerevisiae & KY105179 & 99 & 543 \\
\hline 3 & Saccharomyces cerevisiae & KY105179 & 99 & 609 \\
\hline
\end{tabular}

Table 3: Gene sequences of DNA bands from yeast detected by Gene bank

\section{Effect of Time on Saccharomyces Cerevisiae Biomass}

The results in Table 4 show the effect of time on biomass of yeast. Continuous increment in fermentation time led to a significant increase in quantity of biomass of yeast produced from 0 to $24 \mathrm{~h}$. Biomass increased at each 4 hour interval, from $1.00 \mathrm{~g} \mathrm{~L}^{-1}$ to 6.82 $\mathrm{g} \mathrm{L}^{-1}$. There were significantly difference on biomass of yeast from 0 to $12 \mathrm{~h}(\mathrm{p}<0.05)$. Biomass was highest at $24 \mathrm{~h}$, reached $7.91 \mathrm{~g}$ $\mathrm{L}^{-1}$ and had tendency reduce at $28 \mathrm{~h}$, reached $7.62 \mathrm{~g} \mathrm{~L}^{-1}$. However, there were no significant difference on biomass of yeast at $24 \mathrm{~h}$ and $28 \mathrm{~h}(\mathrm{p}>0.05)$.

\begin{tabular}{|c|c|c|c|}
\hline Time & Mean & \multicolumn{2}{|c|}{$95 \%$ Confidence Interval } \\
\hline & & Lower Bound & Upper Bound \\
\hline 0 & $1.00^{\mathrm{a}}$ & 0.336 & 1.664 \\
\hline 4 & $3.44^{\mathrm{b}}$ & 2.778 & 4.106 \\
\hline 8 & $5.62^{\mathrm{c}}$ & 4.962 & 6.290 \\
\hline 12 & $6.82^{\text {cd }}$ & 6.156 & 7.485 \\
\hline 24 & $7.91^{\mathrm{d}}$ & 7.244 & 8.572 \\
\hline 28 & $7.62^{\mathrm{d}}$ & 6.958 & 8.286 \\
\hline
\end{tabular}

Means within a column with different superscripts are significantly different $(\mathrm{p}<0.05)$

Table 4: Effect of time on Saccharomyces cerevisiae biomass $\left(\mathrm{g} \mathrm{L}^{-1}\right)$

\section{Effect of C/N ratio on Saccharomyces cerevisiae biomass}

The effect of $\mathrm{C} / \mathrm{N}$ ratio on Saccharomyces cerevisiae was displayed in the Table 5 . There were significatly differences $(\mathrm{p}<0.05)$ in biomass of Saccharomyces cerevisiae when using different ratios of $\mathrm{C} / \mathrm{N}$. Biomass of yeast was highest $(\mathrm{p}<0.05)$ for $\mathrm{C} / \mathrm{N}$ ratio at $10 / 1$ and lowest for $\mathrm{C} / \mathrm{N}$ ratio at $15 / 1$ and 5/1. 


\begin{tabular}{|c|c|c|c|}
\hline C/N & Mean & \multicolumn{2}{|c|}{ 95\% Confidence Interval } \\
\hline & & Lower Bound & Upper Bound \\
\hline $10 / 1$ & $6.68^{\mathrm{a}}$ & 6.213 & 7.152 \\
\hline $15 / 1$ & $4.71^{\mathrm{b}}$ & 4.237 & 5.177 \\
\hline $5 / 1$ & $4.82^{\mathrm{b}}$ & 4.351 & 5.290 \\
\hline
\end{tabular}

Means within a column with different superscripts are significantly different $(\mathrm{p}<0.05)$

Table 5: Effect of urea concentration on Saccharomyces cerevisiae biomass $\left(\mathrm{g} \mathrm{L}^{-1}\right)$

\section{Effect of Molasses Concentration on Saccharomyces Cerevisiae Biomass}

In order to estimate Saccharomyces cerevisiae biomass production in molasses medium containing different $\mathrm{C} / \mathrm{N}$ ratios, the cell biomass was collected at different fermentation time $0,4,8,12,24$ and $28 \mathrm{~h}$. At $\mathrm{C} / \mathrm{N}$ ratio of 5/1, the yeast biomass was highest at molasses concentrations of $23.33 \mathrm{~g}$, respectively $6.49 \mathrm{~g} \mathrm{~L}^{-1}$ (Graph 1). At $\mathrm{C} / \mathrm{N}$ ratio of 10/1, the yeast biomass was highest at molasses concentration of $35.00 \mathrm{~g}$, respectively $7.57 \mathrm{~g} \mathrm{~L}^{-1}$ (Graph 2). At $\mathrm{C} / \mathrm{N}$ ratio of 15/1, the yeast biomass was lowest at molasses concentration of $70 \mathrm{~g} \mathrm{~L}^{-1}$, respectively $2.79 \mathrm{~g} \mathrm{~L}^{-1}$ (Graph 3). The results showed that too low or too high levels of molasses concentration also affect the growth of Saccharomyces cerevisiae.

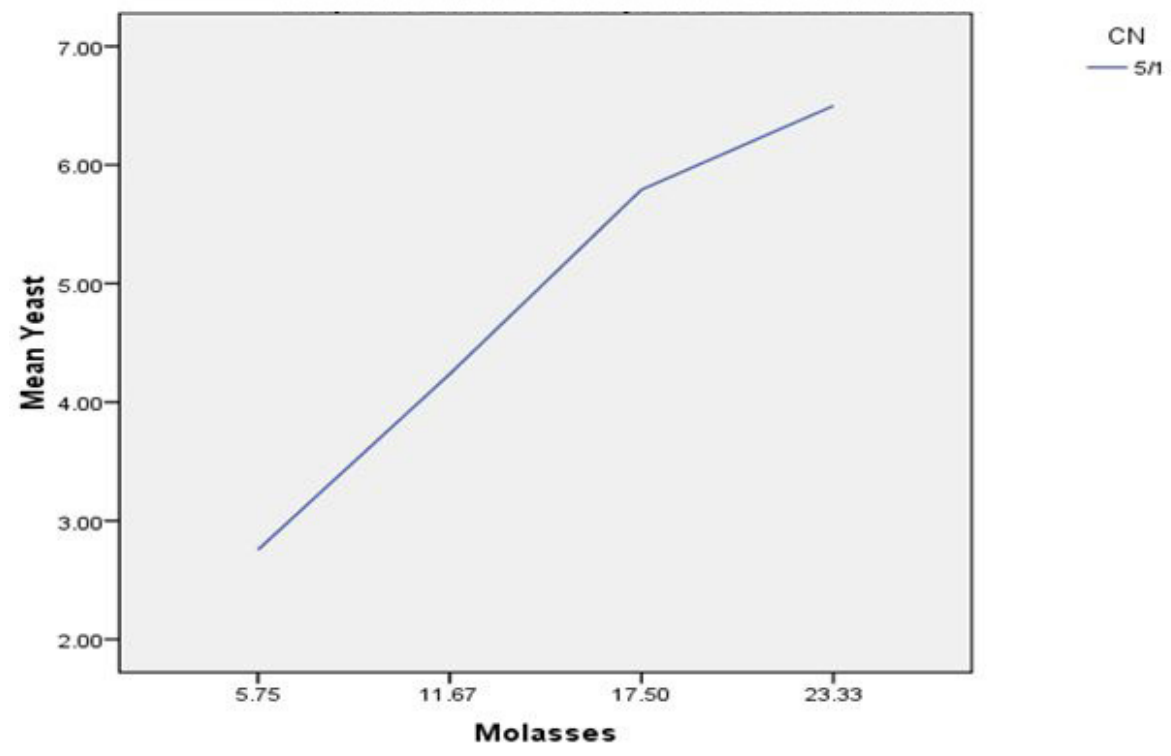

Graph 1: Biomass of Veast at C/N ratio of 5/1

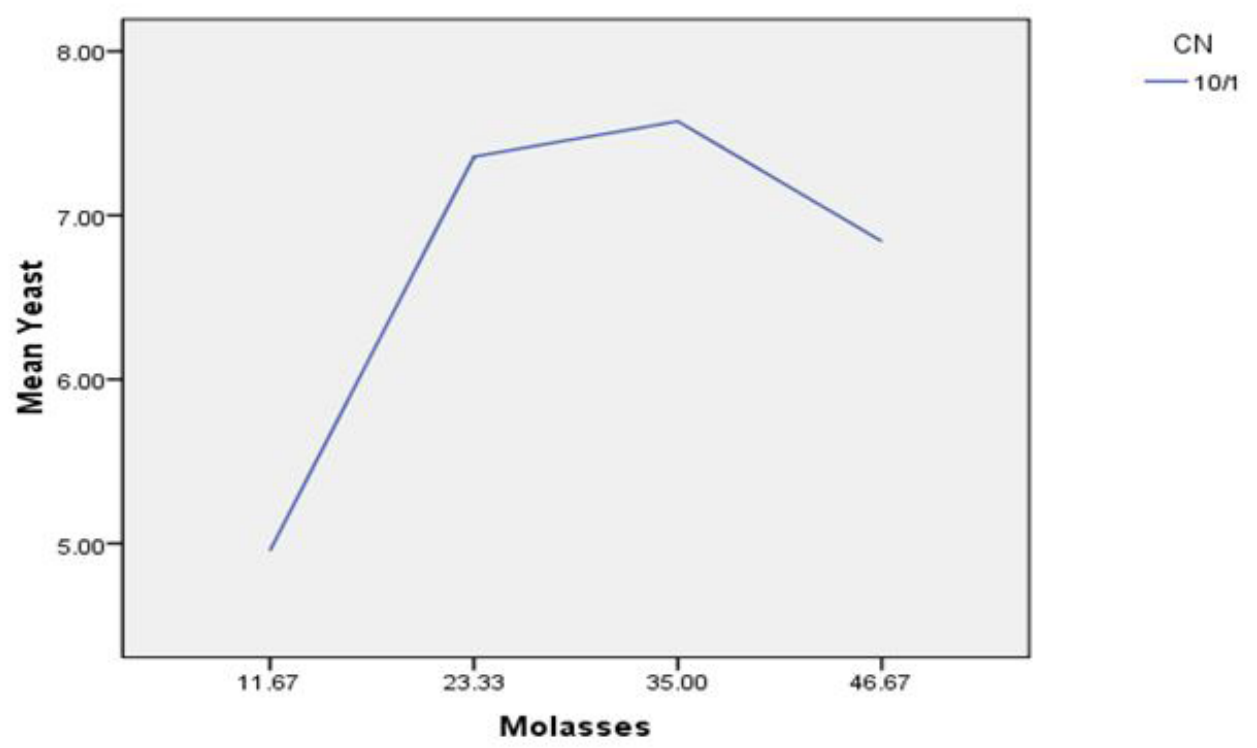

Graph 2: Biomass of yeast at C/N ratio of 10/1 
Graph 3: Biomass of yeast at C/N ratio of $15 / 1$

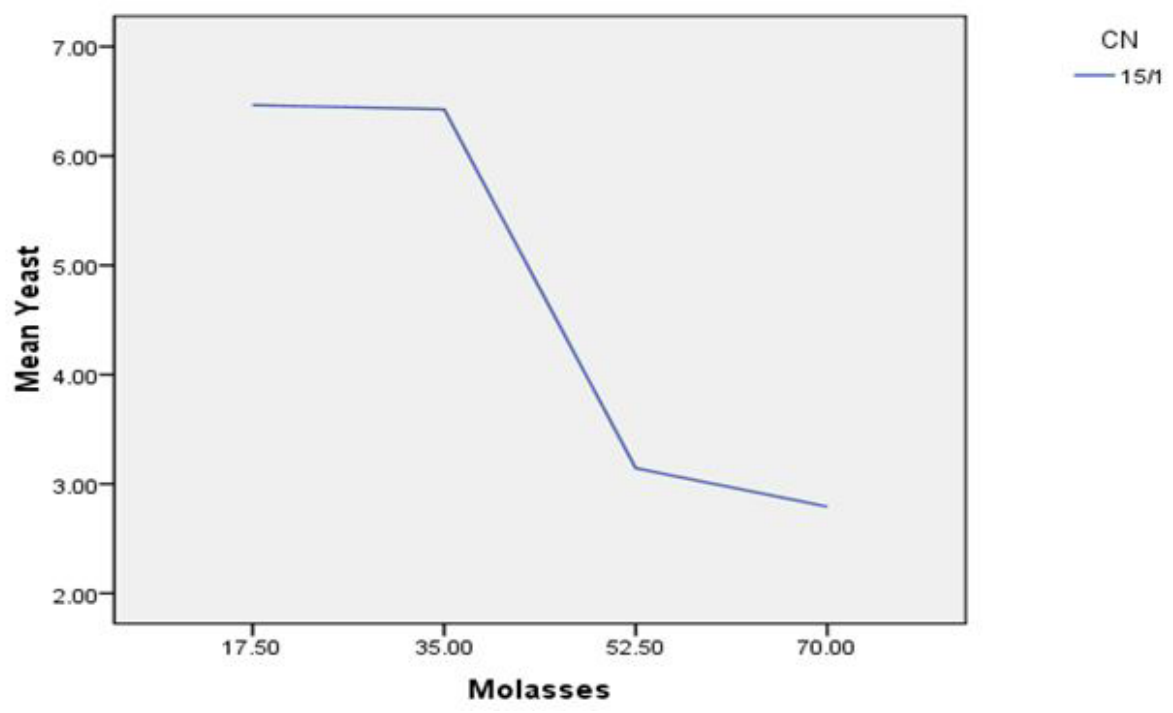

Graph 3: Biomass of yeast at $\mathrm{C} / \mathrm{N}$ ratio of $15 / 1$

\section{Discussions}

Yeast is the first microorganism to be used as a feed supplement for animals. Yeast has high nutritional value. Yeast contains $45-55 \%$ protein, $2-6 \%$ fat, $5-10 \%$ ash [21]. Yeast is one of the microorganisms used to produce single-celled proteins because yeast can be used in a wide variety of substrates such as agricultural and industrial byproducts [1]. In order to estimate density of yeast in Feed Active Dry Yeast product for further study, $1 \mathrm{~g}$ product was diluted in sterile distilled water from $10^{-1}$ to $10^{-8}$. Then $100 \mu \mathrm{l}$ dilute solution were cultured on YPD medium, incubated for $48 \mathrm{~h}$ at $30^{\circ} \mathrm{C}$ and monitored after 3 days. The result of colony forming units $(\mathrm{CFU} / \mathrm{g})$ was $21.86 \times 10^{9} \mathrm{CFU} / \mathrm{g}$ products. Our result was similar with data reported from company. This product has a moisture content of lower than $10 \%$, great advantage is long time use and easy transport.

Yeast has an important role for food fermentation to produce bread and bakery products. The fermentation parameters are clearly related to the yeast flora genotypical characteristics. Therefore, the accurate identification of yeast species is very important. Traditional method for identifying yeast requires laborious and time consuming. In recently, a non-conventional sensitive and specific method for the detection of Saccharomyces cerevisiae in food is proposed. Polymerase chain reaction (PCR) led to the identification of this yeast in some commercial bakery products [22]. Molecular method has been used successfully to identify yeast by ITS1 and ITS4 regions [22,23]. Analysis DNA band of ITS1 and ITS4 region of yeast shows that amplified products for yeast. Internal transcribed spacer amplification (ITS1/ITS4) produced a single band of about 800 bp for yeast. The result of this study was similar with Arlorio et al., (1999) [22]. The data in Table 3 indicated that utility of ITS1 and ITS4 sequences for distinguishing yeasts. All sequences were compared with known strains using NCBI-BLAST2 Nucleotide search (www.ebi.ac.uk/; http://blast.ncbi.nlm.nih.goverevisiae/). All three sequences was closest sequence with Saccharomyces cerevisiae with high identity of $99 \%$. That is similar with species of product.

Saccharomyces cerevisiae is suitable for single cell protein production at commercial scale because of its nutritional quality (protein content 45-55\%). Yeast can grow up on different carbon sources such as lactose, pentose, maltose, molasses, and agricultural or industrial wastes $[1,24,25]$. Recently, some studies have shown that different rates of C: $\mathrm{N}$ affects the biomass of yeast cells. The result for cell concentration was highest at a C: N ratio of 10 [11]. According to Sarlin and Philip, (2013), molasses medium was most suitable for growth of the yeast to compare with glucose, sucrose and rice water [24]. In this study, molasses that is a byproduct of the sugar manufacturing was used as a sole source of carbon and nitrogen source was from urea. The reason to add urea as a nitrogen source in to molasses medium because of molasses contains low nitrogen. The molasses concentrations were calculated in the $\mathrm{C} / \mathrm{N}$ ratios of $5 / 1 ; 10 / 1$ and $15 / 1$ at different levels of urea $0.5 ; 1.0 ; 1.5$ and $2.0 \%$ (Table 1 ). The results showed that the highest biomass of Saccharomyces cerevisiae was observed at ratios of $\mathrm{C} / \mathrm{N}$ of $15 / 1$ and $5 / 1$, reached 4.71 and $4.82 \mathrm{~g}$ L-1, respectively (Table 5). Specifically, the cell biomass obtained in the molasses concentration of $35.00 \mathrm{~g}$ was $7.57 \mathrm{~g}$ L-1 and lowest in the molasses concentration of $5.75 \mathrm{~g}, 11.67 \mathrm{~g}, 52.50 \mathrm{~g}$ and $70.00 \mathrm{~g}$ were $2.75 \mathrm{~g} \mathrm{~L}-1,4.96 \mathrm{~g} \mathrm{~L}-1,3.14 \mathrm{~g} \mathrm{~L}-1$, and $2.79 \mathrm{~g}$ L-1, with a C/N ratio of 5/1,10/1 and 15/1, respectively. The results of this study are similar to the results of Danesi et al. (2006) when culturing recombinant Saccharomyces cerevisiae at $\mathrm{C} / \mathrm{N}$ ratio of 10/1, which also obtained the highest biomass. Kalil, et al. (2008) and Manikandan and Viruthagiri (2010) reported that nitrogen source, nitrogen concentration and carbon to nitrogen ratio affect biomass concentration. Kalil, et al. (2008) used organic (pepton, trypton, yeast extract) and inorganic (ammonium sulfate, ammonium nitrate, ammonium chloride) nitrogen to find the best source of nitrogen for biomass production. The result shown that organic nitrogen was better for bacterial growth, and the nitrogen concentration affects bacterial growth [14,26]. Sarlina and 
Philip, (2013) showed that both molasses concentration and organic nitrogen (pepton, yeast extract) concentration influenced biomass of yeast. The result of this study also demonstrated both $\mathrm{C} / \mathrm{N}$ ratio and molasses concentration influenced biomass of Saccharomyces cerevisiae [24,27].

\section{Conclusion}

This study concluded that time, $\mathrm{C} / \mathrm{N}$ ratio and molasses concentration within $\mathrm{C} / \mathrm{N}$ ratio affect biomass production of Saccharomyces cerevisiae yeast. As the results, molasses concentration of $35 \mathrm{~g}, \mathrm{C} / \mathrm{N}$ ratio and the time of fermentation of $24 \mathrm{~h}$ resulted the highest biomass production of Saccharomyces cerevisiae.

\section{Acknowledgement}

The author would like to the thank MEKARN II project for financial support.

\section{References}

1. Nasseri AT, Rasoul-Amini S, Morowvat MH, Ghasemi Y (2011) Single cell protein: Production and Process. Am J Biochem Biotechnoli 6: 103-16.

2. Hughes P, Heritage J (2004) Antibiotic growth-promoters in food animals 129-51.

3. Maron DF, Smith JST, Nachman EK (2013) Restrictions on antimicrobial use in food animal production: an international regulatory and economic survey. Global Health 9: 48

4. Price KL, Totty HR, Lee HB, Utt MD, Fitzner GE, et al. (2010) Use of Saccharomyces cerevisiae fermentation product on growth performance and microbiota of weaned pigs during Salmonella infection J Anim Sci 88: 3896-908.

5. Schen YB, Fellner V, Yoon I, Kim SW (2017) Effect of dietary supplementation of Saccharomyces cerevisiae fermentation product to sows and their offspring on growth and meat quality. Transl Anim Sci 1: 45-53.

6. Jiang X, Overholtzer M, Thompson Bc (2015) Autophagy in cellular metabolism and cancer 125: 47-54.

7. Boonnop K, Wanapat M, Nontaso N, Wanapat S (2009) Enriching nutritive value of cassava root by yeast fermentation. Sci Agric 66: 629-33.

8. Oboh G, Akindahunsi AA (2005) Nutritional and toxicological evaluation of Saccharomyces cerevisiae fermented cassava flour. J Food Compost Anal 18: 731-8.

9. Thongkratok R, Khempaka S, Molee W (2010) Protein enrichment of cassava pulp using microorganisms fermentation techniques for use as an alternative animal feedstuff. J Anim Vet Advances 9: 2859-62.

10. Tefera T, Ameha K and Biruhtesfa A (2014) Cassava based foods: microbial fermentation by single starter culture towards cyanide reduction, protein enhancement and palatability. Int Food Res J 21: 1751-6

11. Danesi EDG, Miguel ASM, Rangel-Yagui CO, Carvalho JCM, Pessoa A, et al. (2006) Effect of carbon:nitrogen ratio (C:N) and substrate source on glucose-6phosphate dehydrogenase (G6PDH) production by recombinant Saccharomyces cerevisiae. J Food Eng 75: 96-103.

12. Oura E (1974) Effect of aeration intensity on the biochemical composition of baker's yeast.I. Factors affecting the type of metabolism. Biotechnol Bioeng 16 : $1197-212$.

13. Woehrer W, Roehr M (1981) Regulatory aspects of baker's yeast metabolism in aerobic fed-batch cultures. Biotechnol Bioeng 567-81.

14. Manikandan K, Viruthagiri T (2010) Optimization of C/N ratio of the medium and fermentation conditions of ethanol production from Tapioca starch using co-culture of Aspergillus niger and Saccharomyces cerevisiae. Int J ChemTech Res 2: 947-55.

15. Sauer N, Mosenthin R, Bauer E (2011) The role of dietary nucleotides in single-stomached animals 24: 46-59,

16. Jiang Z, Wei S, Wang Z, Zhu C, Hu S, et al. (2015) Effect of different forms of yeast Saccharomyces cerevisiae on growth performance, intestinal development, and systemic immunity in early-weaned piglets. Nutr Res Rev 6: 47.

17. Kim J, Hosseindoust A, Lee S, Choi Y, Kim MJ, et al. (2017) Bacteriophage cocktail and multi-strain probiotics in the feed for weanling pigs: effects on intestine morphology and targeted intestinal coliforms and clostridium. Animal 11: 45-53.

18. Bontempo V, Di Giancamillo A, Savoini G, Dell'Orto V, Domeneghini C (2006) Live yeast dietary supplementation Acts upon intestinal morpho-functional aspects and growth in weanling piglets. Anim Feed Sci Technol 129: 224-36.

19. Avnimelech Y (1999) Carbon/nitrogen ratio as a control element in aquaculture systems. Aquaculture 176: 227-35.

20. Willett D, Morrison C (2006) Using molasses to control inorganic nitrogen and $\mathrm{pH}$ in aquaculture ponds. Queensland Aquaculture News $28: 6-7$.

21. Adedayo MR, Ajiboye EA, Akintunde JK, Odaibo A (2011) Single cell proteins: as nutritional enhancer. Advances in Applied Sci Res 2: 396-409.

22. Arlorio M, Coïsson JD, Martelli A (1999) Identification of Saccharomyces cerevisiae in bakery products by PCR amplification of the ITS region of ribosomal DNA. European Food Res Tech 209: 185-91.

23. Chen YC, Eisner JD, Kattar MM, Rassoulian-Barrett SL, Lafe K, Bui U, et al. (2001) Polymorphic internal transcribed spacer region 1 DNA sequences identify medically important yeast. J Clin Microbiol 39: 4042-51.

24. Sarlin PJ and Philip R (2013) A molasses based fermentation medium for marine yeast biomass production. Int J Res Mar Sci 2: 39-44.

25. Onyegbado CO, Edeh I (2012) Performance of yeast cultures in cassava wastes. J Biochem Tech 3: 414-8.

26. Kalil MS, Alshiyab HS, Yusoff WMW (2008) Effect of nitrogen source and carbon to nitrogen ratio on hydrogen production using C. acetobutylicum. Am J Biochem Biotechnol 4: 393-401.

27. Paul EA, Van Veen JA (1978) The use of tracer to determine the dynamic nature of organic matter. Proceedings of the 11th International Congress of Soil Science, Edmonton, Canada 3: 6-102. 